\title{
$17 \beta$-Estradiol abrogates apoptosis in murine skeletal muscle cells through estrogen receptors: role of the phosphatidylinositol 3-kinase/Akt pathway
}

\author{
Andrea Vasconsuelo, Lorena Milanesi and Ricardo Boland \\ Departamento de Biología, Bioquímica y Farmacia, Universidad Nacional del Sur, San Juan 670, 8000 Bahía Blanca, Argentina \\ (Correspondence should be addressed to R Boland; Email: rboland@criba.edu.ar)
}

\begin{abstract}
Estrogens can regulate apoptosis in various cellular systems. The present study shows that $17 \beta$-estradiol $\left(\mathrm{E}_{2}\right)$, at physiological concentrations, abrogates DNA damage, poly (ADP-ribose) polymerase cleavage, and mitochondrial cytochrome $c$ release induced by $\mathrm{H}_{2} \mathrm{O}_{2}$ or etoposide in mouse skeletal muscle $\mathrm{C} 2 \mathrm{C} 12$ cells. This protective action, which involved PI3K/Akt activation and Bcl-2 associated death agonist (BAD) phosphorylation, was inhibited by antibodies against the estrogen receptor (ER) $\alpha$ or $\beta$ isoforms, or transfecting siRNA specific for each isoform. The inhibition of the antiapoptotic action of
\end{abstract}

$E_{2}$ at the mitochondrial level was more pronounced when ER- $\beta$ was immunoneutralized or suppressed by mRNA silencing, whereas transfection of $\mathrm{C} 2 \mathrm{C} 12$ cells with either $\mathrm{ER}-\alpha$ siRNA or ER- $\beta$ siRNA blocked the activation of $A k t$ by $E_{2}$, suggesting differential involvement of ER isoforms depending on the step of the apoptotic/survival pathway evaluated. These results indicate that $\mathrm{E}_{2}$ exerts antiapoptotic effects in skeletal muscle cells which are mediated by ER- $\beta$ and ER- $\alpha$ and involve the $\mathrm{PI} 3 \mathrm{~K} /$ Akt pathway.

Journal of Endocrinology (2008) 196, 385-397

\section{Introduction}

The estrogen $17 \beta$-estradiol $\left(\mathrm{E}_{2}\right)$ is a steroid hormone whose actions involve genomic and non-genomic mechanisms (Bjornstrom \& Sjoberg 2005). It is generally accepted that the majority of the effects of the hormone are mediated via two estrogen receptors (ERs), namely ER- $\alpha$ and ER- $\beta$, which are members of the nuclear receptor superfamily, by regulating nuclear estrogen responsive genes (Evans 1988, Tsai \& O'Malley 1994, Beato et al. 1996, Pettersson et al. 2000, Hall et al. 2001, Hewitt \& Korach 2002). Also, several investigators have pointed out the possibility that the ER could be non-classically associated with intracellular membranes (Parikh et al. 1980, Watson \& Muldoon 1985, Muldoon et al. 1988, Monje \& Boland 1999, Watson et al. 1999). Moreover, there is evidence showing that ER- $\alpha$ and ER- $\beta$ may be located in the plasma membrane (Luconi et al. 1999, Norfleet et al. 2000, Ropero et al. 2002, Monje \& Boland 2001, Monje et al. 2001, Li et al. 2003) and mitochondrial compartments (Zheng \& Ramirez 1999, Horvat et al. 2001, Monje \& Boland 2002, Yang et al. 2004, Solakidia et al. 2005). In addition, the non-genomic events triggered by $\mathrm{E}_{2}$ suggest the ability of the hormone to activate extranuclear receptors (Bjornstrom \& Sjoberg 2005). Among the rapid nontranscriptional actions of $\mathrm{E}_{2}$, the activation of the phosphatidylinositol 3-kinase (PI3K) / Akt pathway has been shown in various cellular lines (Fernando \& Wimalasena 2004, Guo et al. 2006). $\mathrm{PI} 3 \mathrm{~K}$ regulates phosphoinositide metabolism and is responsible for the generation of phosphatidylinositol-3,4,5-trisphosphate
( $\mathrm{PIP}_{3}$; Vanhaesebroeck et al. 2001, Osaki et al. 2004). The activation of $\mathrm{PI} 3 \mathrm{~K}$ results in $\mathrm{PIP}_{3}$-mediated activation of the serine-threonine kinase Akt by phosphorylation. In turn, phospho-Akt modulates the function of numerous substrates involved in the regulation of cell functions as for example apoptosis (Coffer et al. 1998, Vanhaesebroeck et al. 2001). There is evidence that $E_{2}$ is able to promptly activate the PI3K/Akt pathway by different mechanisms, in an ER-dependent and ER-independent manner, depending on the cellular type (Guo et al. 2006). Accordingly, estrogens exert antiapoptotic effects on various cell types such as vascular endothelial, smooth muscle, and breast cancer cells, among others (Spyridopoulos et al. 1997, Sudoh et al. 1998, Razandi et al. 2000).

There is evidence that skeletal muscle is a target tissue for estrogens. Muscle mass and strength diminish during the postmenopausal years leading to sarcopenia which is a risk factor for osteoporosis since it is associated with physical disability and immobility resulting in bone loss. Sarcopenia depends, in part, on estrogen levels. Thus, hormone replacement therapies prevent a decline in muscle performance (Dionne et al. 2000). Congruent with these observations, it has been recently established that human skeletal muscle contains ER- $\alpha$ and ER- $\beta$ (Lemoine et al. 2003, Wiik et al. 2003), although the exact mechanism by which estrogens prevent sarcopenia remains to be clarified.

It has been shown that estrogens promote proliferation and differentiation of skeletal myoblasts (Kahlert et al. 1997). Moreover, studies with myoblasts have demonstrated that 
A

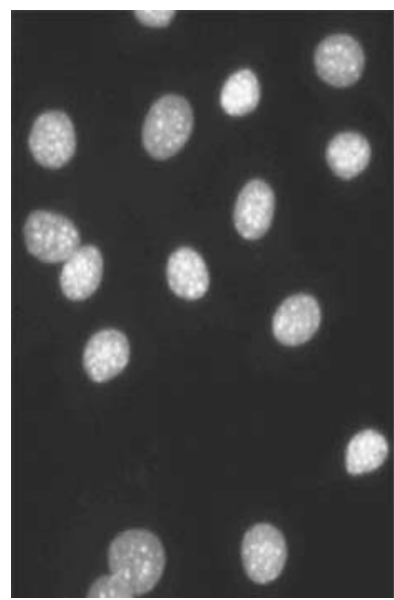

Control

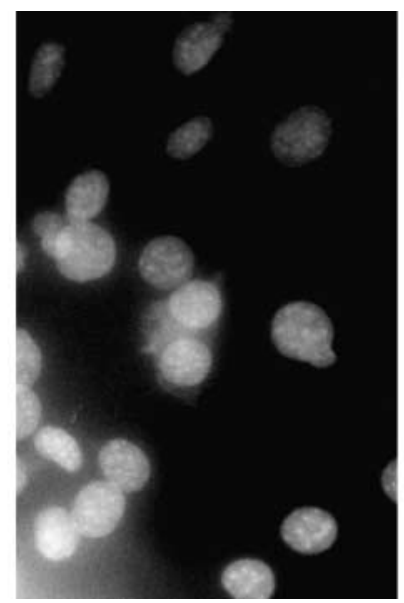

$\mathrm{E}_{2}$

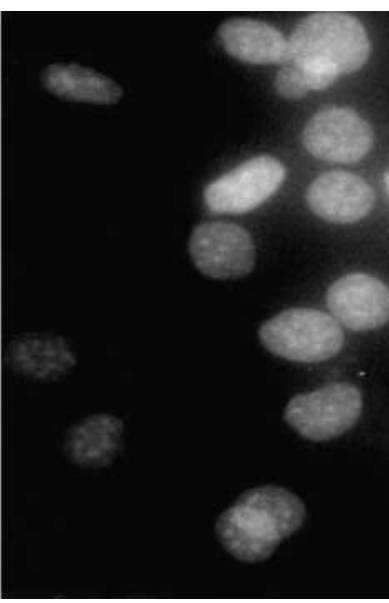

$\mathrm{E}_{2}+\mathrm{H}_{2} \mathrm{O}_{2}$

B
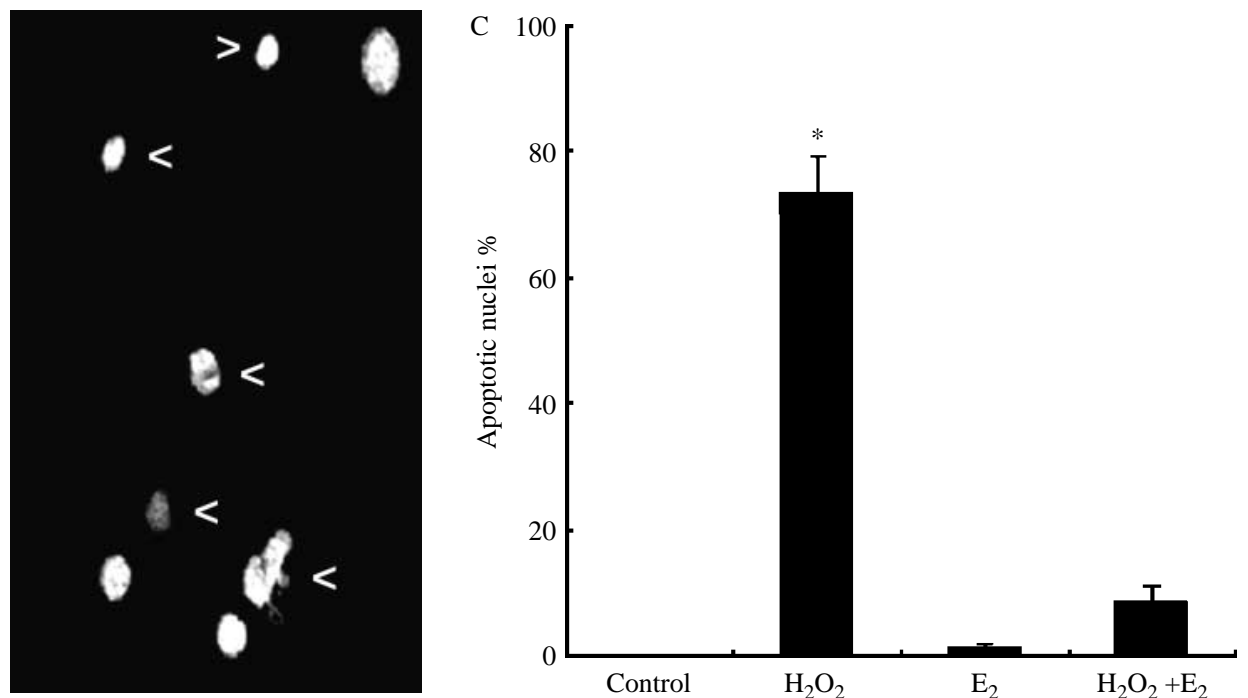

Figure 1 Inhibition of $\mathrm{H}_{2} \mathrm{O}_{2}$-induced apoptosis by $17 \beta$-estradiol in $\mathrm{C} 2 \mathrm{C} 12$ muscle cells. Cultured $\mathrm{C} 2 \mathrm{C} 12$ cells were treated with $0.5 \mathrm{mM} \mathrm{H}_{2} \mathrm{O}_{2}\left(\mathrm{H}_{2} \mathrm{O}_{2}\right)$ for $24 \mathrm{~h}$ or preincubated with $10^{-8} \mathrm{M} 17 \beta$-estradiol before addition of $\mathrm{H}_{2} \mathrm{O}_{2}\left(\mathrm{E}_{2}+\mathrm{H}_{2} \mathrm{O}_{2}\right)$. The cells were then stained with DAPI as described under Materials and Methods. Morphological analysis of fluorescence-stained nuclei is shown. (A) Control- (untreated C2C12 cells cultured in regular medium), $\mathrm{E}_{2}-$, or $\mathrm{E}_{2}+\mathrm{H}_{2} \mathrm{O}_{2}$-treated cells, with normal nuclear morphology. (B) Apoptotic cells $\left(+\mathrm{H}_{2} \mathrm{O}_{2}\right)$ with pyknotic nuclei, condensed chromatin or DNA fragmentation (arrowheads). (C) Percentages of apoptotic cells at each condition. At least ten fields per dish were examined. Each value represents the mean of three independent experiments \pm s.D. ${ }^{*} P<0 \cdot 05$ with respect to the control. Representative photographs of apoptotic and normal cells are shown. Experiments were repeated at least three times with essentially identical results.

apoptosis plays an important role in skeletal muscle development, by controlling the size of the population of proliferating myoblasts which undergo differentiation into mature myotubes (Walsh 1997, Sandri \& Carraro 1999, Huppertz et al. 2001). Then, the effects of the hormone on skeletal muscle development could also be regulated, in part, through its effects on apoptosis.

In view of the above lines of evidence, the objective of the present work was to investigate whether $E_{2}$ exerts a regulatory action on apoptosis in skeletal muscle and to obtain information on the mechanism involved therein. To that end, $\mathrm{C} 2 \mathrm{C} 12$ murine skeletal muscle cells treated with etoposide or hydrogen peroxide $\left(\mathrm{H}_{2} \mathrm{O}_{2}\right)$ were used as experimental model. $\mathrm{H}_{2} \mathrm{O}_{2}$ and etoposide, a topoisomerase II inhibitor, have been widely used as inducers of apoptosis and a substantial literature details many biochemical events that occur upon apoptotic induction by both agents in a variety of cell types including C2C12 muscle cells (Mizumoto et al. 1994, Kavurma \& Khachigian 2003, Biswas et al. 2005, Jiang et al. 2005a,b). The data obtained demonstrate 


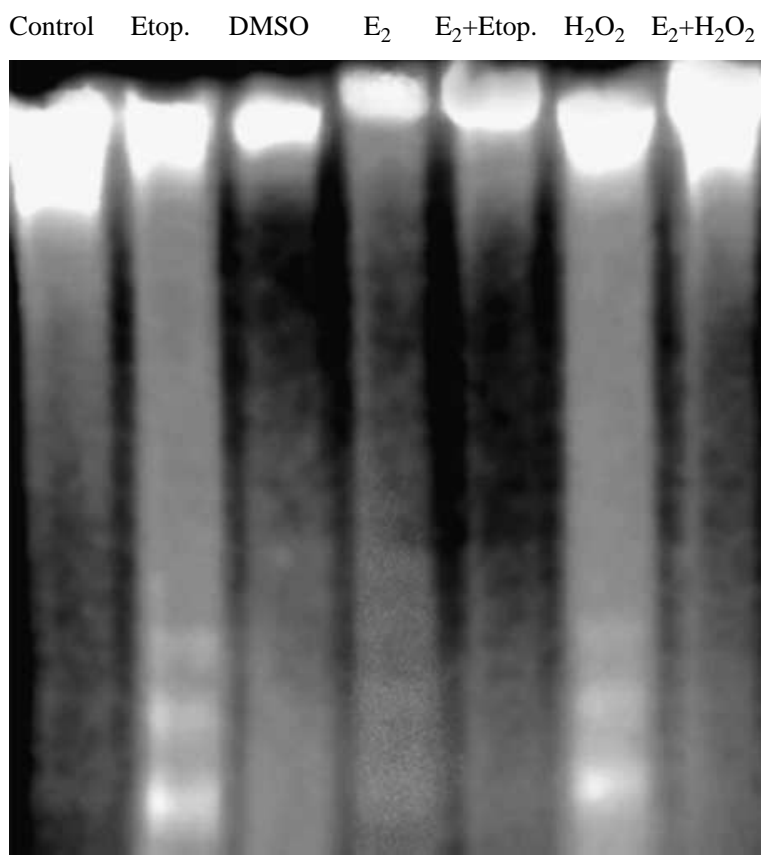

Figure 2 Inhibition of $\mathrm{H}_{2} \mathrm{O}_{2}$-or etoposide-induced DNA fragmentation by $17 \beta$-estradiol in $\mathrm{C} 2 \mathrm{C} 12$ muscle cells. After treatments, DNA was extracted from $\mathrm{C} 2 \mathrm{C} 12$ cells as described under Materials and Methods, separated by electrophoresis on agarose gels, stained with ethidium bromide and visualized under u.v. light. Control, untreated cells; Etop., cells treated with $25 \mu \mathrm{g} / \mathrm{ml}$ etoposide for $24 \mathrm{~h}$; DMSO, cells treated with etoposide dissolvent; $\mathrm{E}_{2}$, cells treated with $10^{-8} \mathrm{M} 17 \beta$-estradiol for $45 \mathrm{~min} ; \mathrm{E}_{2}+$ Etop., cells preincubated with $10^{-8} \mathrm{M} 17 \beta$-estradiol for $45 \mathrm{~min}$ and then treated with $25 \mu \mathrm{g} / \mathrm{ml}$ etoposide for $24 \mathrm{~h} ; \mathrm{H}_{2} \mathrm{O}_{2}$, cells treated with $0.5 \mathrm{mM} \mathrm{H} \mathrm{O}_{2}$ during $24 \mathrm{~h} ; \mathrm{H}_{2} \mathrm{O}_{2}+\mathrm{E}_{2}$, cells preincubated with $10^{-8} \mathrm{M} 17 \beta$-estradiol for $45 \mathrm{~min}$ and then treated with $0.5 \mathrm{mM}$ $\mathrm{H}_{2} \mathrm{O}_{2}$ during $24 \mathrm{~h}$. Experiments were repeated at least three times with essentially identical results.

an antiapoptotic action of $\mathrm{E}_{2}$ in $\mathrm{C} 2 \mathrm{C} 12$ skeletal muscle cells exposed to etoposide or oxidative stress $\left(\mathrm{H}_{2} \mathrm{O}_{2}\right)$, which requires $\mathrm{PI} 3 \mathrm{~K} / \mathrm{Akt}$ activation and is mediated by ER- $\beta$ and ER- $\alpha$.

\section{Materials and Methods}

\section{Materials}

ER- $\alpha$ mouse monoclonal antibody Ab-10/clon TE111.5D11 (anti-ER ligand binding domain) was purchased from NeoMarkers (Fremont, CA, USA). ER- $\beta$ goat polyclonal antibodies L-20 (mapping near C-terminus) and Y-19 (mapping at the $\mathrm{N}$-terminus), and anti-lamin $\mathrm{B}$ were purchased from Santa Cruz Biotechnology Inc. (Santa Cruz, CA, USA). PhosphoDetect anti-Bad (Ser136) and anti-poly (ADP-ribose) polymerase (PARP) pAb were from Calbiochem (San Diego, CA, USA). Anti-phospho-Akt (Ser473) was from Cell Signaling Technology Inc (Danvers, MA, USA). DAPI and MitoTracker Red (MitoTracker Red CMXRos) dyes were from Molecular Probes (Eugene, OR, USA). ER- $\alpha$ and ER- $\beta$ ShortCut siRNA, fluorescein-siRNA transfection control and TransPass R2 transfection reagent were from New England Biolabs (NEB, Beverly, MA, USA). ICI 182780 was from Tocris (Ellisville, MO, USA). Cytochrome $c$ oxidase assay kit, etoposide, $\mathrm{E}_{2}$-peroxidase and diethylstilbestrol (DES) were purchased from Sigma-Aldrich. DNAzol Reagent was from GIBCO BRL. The PI3K inhibitors wortmannin and LY294002 were obtained from Alomone Labs Ltd (Jerusalem, Israel). All the other reagents used were of analytical grade.

\section{Cell culture and treatment}

C2C12 murine skeletal muscle cells, kindly donated by Dr Enrique Jaimovich (Universidad de Chile, Santiago, Chile), were cultured in growth medium (Dulbecco's modified Eagle's medium (DMEM) supplemented with 10\% heatinactivated $\left(30 \mathrm{~min}, 56^{\circ} \mathrm{C}\right)$ fetal bovine serum), $1 \%$ nistatine, and $2 \%$ streptomycin. Cells were incubated at $37^{\circ} \mathrm{C}$ in a humid atmosphere of $5 \% \mathrm{CO}_{2}$ in air. Cultures were passaged every 2 days with fresh medium. The treatments were performed with $70-80 \%$ confluent cultures in medium without serum by adding $\mathrm{E}_{2}$, ICI 182780 , or the non-steroidal analog DES, $45 \mathrm{~min}$ before induction of apoptosis with hydrogen peroxide $\left(\mathrm{H}_{2} \mathrm{O}_{2}\right)$ or etoposide during $24 \mathrm{~h}$ or the time indicated in specific experiments. $\mathrm{H}_{2} \mathrm{O}_{2}$ was diluted in culture medium without serum at a final concentration of $0.5 \mathrm{mM}$ in each assay and etoposide was prepared in dimethyl sulfoxide (DMSO) at a final concentration of $25 \mu \mathrm{g} / \mathrm{ml}$ in each assay. Unless otherwise noted, cells were cultured in chamber slides for microscopy.

To block the protective effects of hormone on $\mathrm{H}_{2} \mathrm{O}_{2}$-induced cytochrome $c$ release (determined by evaluation of outer mitochondrial membrane integrity; see below) using different monoclonal antibodies against ER- $\alpha$ and ER- $\beta$, the cultured muscle cells were first permeabilized with saponin $(50 \mu \mathrm{g} / \mathrm{ml}$; $1 \mathrm{~min}$ at $37^{\circ} \mathrm{C}$ ) and then incubated for $1 \mathrm{~h}$ at $37^{\circ} \mathrm{C}$ in presence of a 1:100 dilution of the antibodies in DMEM.

\section{Quantitation of apoptotic cells}

After treatments, the cells were fixed with methanol at $-20{ }^{\circ} \mathrm{C}$ for $30 \mathrm{~min}$ and then washed with PBS. Fixed cells were incubated for $30 \mathrm{~min}$ at room temperature in darkness with 1:500 of a stock solution of DAPI $(5 \mathrm{mg} / \mathrm{ml})$ and next washed with PBS. Cells were mounted on glass slides and examined using a fluorescence microscope (NIKON Eclipse E 600) equipped with standard filter sets to capture fluorescent signals. Images were collected using a digital camera. Apoptotic cells were identified by the condensation and/or fragmentation of their nuclei. The results were expressed as percentage of apoptotic cells. A minimum of 500 cells was counted for each treatment from at least three independent experiments.

\section{Detection of DNA fragmentation}

DNA was extracted from treated or control cells, using DNAzol Reagent (Gibco-BRL) as described by the manufacturer. Isolated 
A

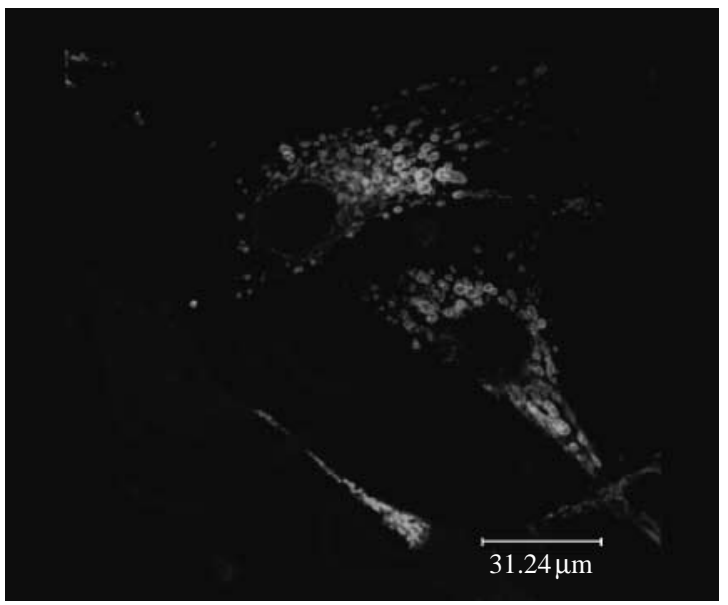

B

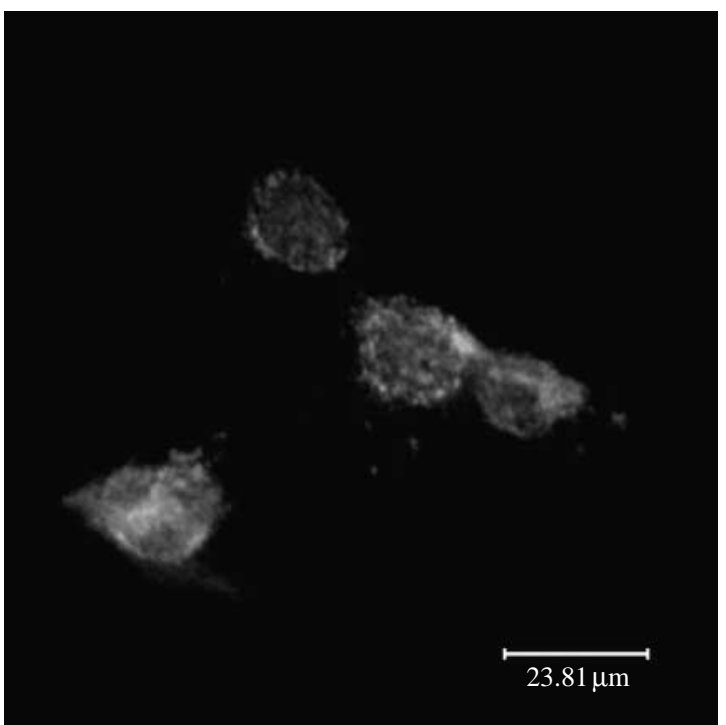

$\mathrm{C}$

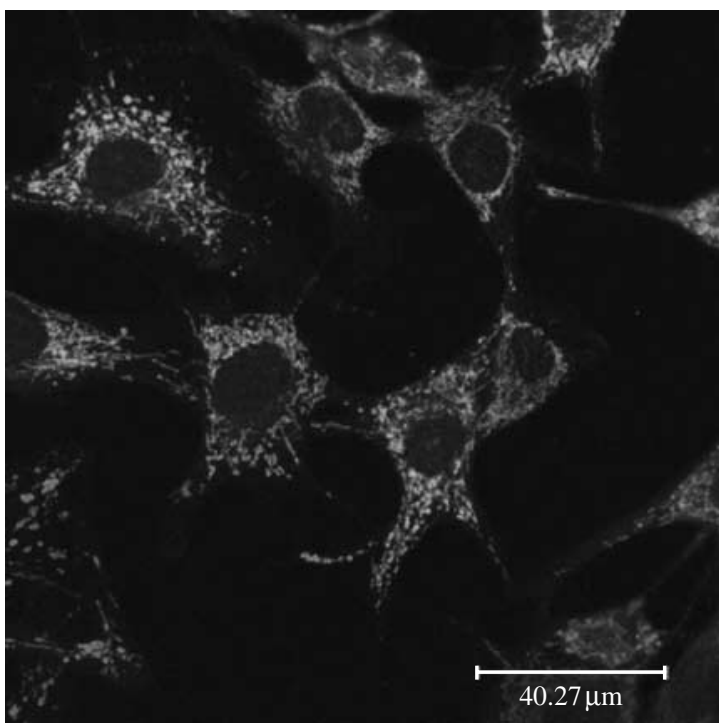

DNA (30 $\mu$ g for each condition) was electrophoresed on a $1.5 \%$ agarose gel in Tris-acetate-EDTA buffer at $40 \mathrm{~mA}$. The gel was stained with ethidium bromide and visualized under u.v. light.

\section{Subcellular fractionation}

C2C12 confluent monolayers were scrapped and homogenized in ice-cold Tris-EDTA-sucrose (TES) buffer $(50 \mathrm{mM}$ Tris- $\mathrm{HCl}$ (pH 7·4), $1 \mathrm{mM}$ EDTA, $250 \mathrm{mM}$ sucrose, $1 \mathrm{mM}$ dithiothreitol (DTT), $0.5 \mathrm{mM}$ phenylmethylsulfonyl fluoride, $20 \mu \mathrm{g} / \mathrm{ml}$ leupeptin, $20 \mu \mathrm{g} / \mathrm{ml}$ aprotinin, $20 \mu \mathrm{g} / \mathrm{ml}$ trypsin inhibitor) using a Teflon-glass hand homogenizer. A nuclear pellet was obtained by low speed centrifugation $(800 \mathrm{~g}, 20 \mathrm{~min}$ ) of the lysed cell preparation. The supernatant was further centrifuged at $10000 \mathrm{~g}$ for $15 \mathrm{~min}$ to pellet mitochondria. The remaining supernatant was centrifuged at $120000 \boldsymbol{g}$ for $90 \mathrm{~min}$ to yield a soluble supernatant (cytosol) and a plasma membrane-containing particulate pellet (microsomes). Contamination of nuclear, microsomal, and cytosolic fractions with mitochondrial components was assessed by measuring the activity of the mitochondrial marker enzyme cytochrome $c$ oxidase employing the Cytochrome $c$ Oxidase assay kit (Sigma) according to the manufacturer's instructions. Also, anti-lamin B antibody was employed for the immunodetection of the nuclear protein marker lamin B in the different fractions. Negligible crosscontamination of fractions with nuclei and mitochondria was detected (data not shown).

Protein concentration of the fractions was estimated by the method of Bradford (1976), using BSA as standard.

\section{Western blot analysis}

Protein samples $(25 \mu \mathrm{g})$ were mixed with one-fourth of sample buffer (400 mM Tris- $\mathrm{HCl}$ (pH 6.8), 10\% SDS, 50\% glycerol, $500 \mathrm{mM}$ DTT, and $2 \mathrm{mg} / \mathrm{ml}$ bromophenol blue), boiled for $5 \mathrm{~min}$, and resolved by 10\% sodium dodecyl sulfate-PAGE (SDS-PAGE) according to the method of Laemmli (1970). Fractionated proteins were electrotransferred to polyvinylidene fluoride membranes (Immobilon-P) and then blocked for $1 \mathrm{~h}$ at room temperature with $5 \%$ non-fat dry milk in PBS containing $0 \cdot 1 \%$ Tween-20 (PBS-T). Blots were incubated for $1 \mathrm{~h}$ with the appropriate dilution of the primary antibodies: Ab-10/clon

Figure 3 17 $\beta$-Estrdiol inhibits changes in morphology and localization of mitochondria induced by $\mathrm{H}_{2} \mathrm{O}_{2}$ in $\mathrm{C} 2 \mathrm{C} 12$ muscle cells. $\mathrm{C} 2 \mathrm{C} 12$ cells grown on coverslips as $60-70 \%$ confluent monolayers were treated (see below), stained with MitoTracker Red, and fixed with methanol as described under Materials and Methods.

(A) Untreated cells. (B) Cells treated with $0.5 \mathrm{mM} \mathrm{H}_{2} \mathrm{O}_{2}$ during $24 \mathrm{~h}$. (C) Cells preincubated with $10^{-8} \mathrm{M} 17 \beta$-estradiol for $45 \mathrm{~min}$ and then treated with $0.5 \mathrm{mM} \mathrm{H}_{2} \mathrm{O}_{2}$ during $24 \mathrm{~h}$. Cells in $\mathrm{A}$ and $\mathrm{C}$ present normal mitochondrial morphology and distribution throughout the entire cell distant to the nucleus or display 'spiderweb' mitochondria; but cells in B exhibit mitochondria clustered around the nucleus with condensed or pyknotic aspect. At least ten fields per slide and three independent cultures were examined. Representative photographs are shown. Magnification: $63 \times$. 


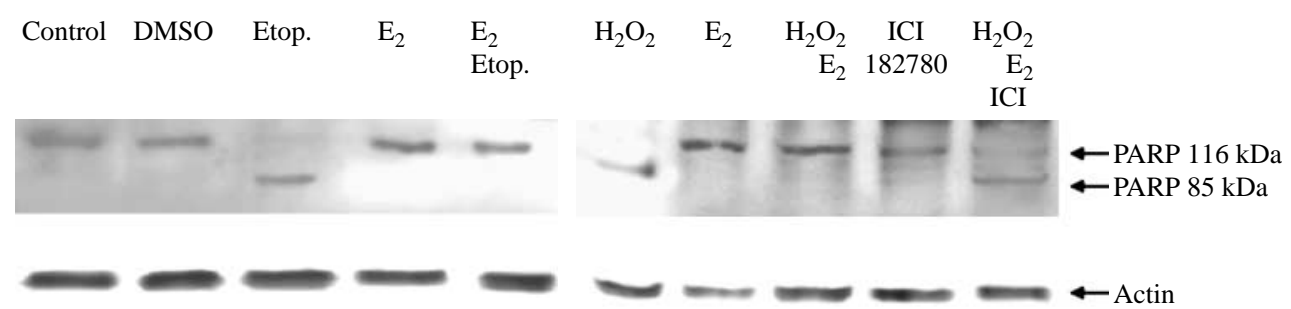

Figure 4 Inhibition of $\mathrm{H}_{2} \mathrm{O}_{2}$ - or etoposide-induced PARP cleavage by $17 \beta$-estradiol. C2C12 cells were treated with the indicated stimuli. Control, untreated cells; DMSO, cells treated with etoposide dissolvent 24 h; Etop., cells treated with $25 \mu \mathrm{g} / \mathrm{ml}$ etoposide for $24 \mathrm{~h}$; $\mathrm{E}_{2}$, cells incubated with $10^{-8} \mathrm{M} 17 \beta$-estradiol for $24 \mathrm{~h}$; $\mathrm{E}_{2}+$ Etop., cells preincubated with $10^{-8} \mathrm{M} 17 \beta$-estradiol for $45 \mathrm{~min}$ and then treated with $25 \mu \mathrm{g} / \mathrm{ml}$ etoposide for $24 \mathrm{~h}$; $\mathrm{H}_{2} \mathrm{O}_{2}$, cells treated with $0.5 \mathrm{mM} \mathrm{H}_{2} \mathrm{O}_{2}$ during $24 \mathrm{~h} ; \mathrm{H}_{2} \mathrm{O}_{2}+\mathrm{E}_{2}$, cells preincubated with $10^{-8} \mathrm{M} 17 \beta$-estradiol for 45 min and then treated with $0.5 \mathrm{mM} \mathrm{H}_{2} \mathrm{O}_{2}$ during $24 \mathrm{~h}$; ICI 182780 , cells incubated with $1 \mu \mathrm{M} \mathrm{ICI} 182780$ for $24 \mathrm{~h} ; \mathrm{ICl}+\mathrm{E}_{2}+\mathrm{H}_{2} \mathrm{O}_{2}$, cells preincubated with $1 \mu \mathrm{M} \mathrm{ICI} 182780$ for $45 \mathrm{~min}$ and then with $17 \beta$-estradiol and $\mathrm{H}_{2} \mathrm{O}_{2}$ as before. Cell lysate proteins from each condition containing equivalent protein amounts $(25 \mu \mathrm{g})$ were fractionated by SDS-PAGE, transferred to PVDF membranes, and western blotted with anti-PARP antibody as described in Materials and Methods. Bands represents uncleaved PARP (116 kDa) and cleavage band at $85 \mathrm{kDa}$. Actin levels are shown as protein loading control. Immunoblots representative are shown. Experiments were repeated at least three times with essentially identical results.

TE111.5D11 anti ER- $\alpha(1: 400)$, anti-lamin B (1:200), anti-phospho-BAD (1:400), anti-PARP pAb (1:200), anti-phospho-Akt (1:1000), using anti-rabbit secondary antibodies for all of them. L-20 (1:300) anti-ER- $\beta$ is an affinity purified goat polyclonal antibody. The membranes were repeatedly washed with PBS-T prior incubation with horseradish peroxidase-conjugated secondary antibodies. The enhanced chemiluminescence (ECL) blot detection kit (Amersham) was used as described by the manufacturer to visualize reactive products. Relative migration of unknown proteins was determined by comparison with molecular weight colored markers (Amersham). For actin loading control, membranes were stripped with stripping buffer $(62.5 \mathrm{mM}$ Tris- $\mathrm{HCl} \quad(\mathrm{pH} \quad 6.7) ; \quad 2 \% \quad$ SDS; $50 \mathrm{mM}$ $\beta$-mercaptoethanol) and then blocked for $1 \mathrm{~h}$ with $5 \%$ non-fat dry milk in PBS containing $0 \cdot 1 \%$ Tween-20 (PBS-T). The blots were then incubated $1 \mathrm{~h}$ with a 1:20 000 dilution of anti-actin policlonal antibody (A-5060) as primary antibody.

After several washings with PBS-T, membranes were incubated with anti-rabbit $(1: 10000)$ or anti-goat $(1: 50000)$ secondary antibodies, depending on the source of the primary antibody, conjugated to horseradish peroxidase. The corresponding immunoreactive bands were developed by means of ECL.

ER- $\alpha$ recombinant protein and ER- $\beta$ blocking peptides were used to confirm the specificity of antibodies used in the assays. Secondary antibodies alone were also employed as a negative control in western blots (Milanesi, de Boland and Boland submitted). All the antibodies employed were tested in the MCF-7 cell line and in cytosolic preparations from rabbit uterus and ovary (Monje \& Boland 1999, 2001).

\section{Transfection of short interfering RNA (siRNA)}

Transfection was performed with a culture cellular density reaching $40-60 \%$ confluence with ER- $\alpha$ or ER- $\beta$ ShortCut siRNA (NEB) according to the manufacturer's instructions. Briefly, TransPass R2 Transfection Reagent was mixed with
ER- $\alpha$ or ER $-\beta$ siRNAs (NEB). The mix was incubated for $20 \mathrm{~min}$ at room temperature and diluted with complete culture medium. The culture medium of the cells was aspirated and replaced with the diluted transfection complex mixture. The cells transfected were used in the indicated assays.

To estimate the transfection efficiency of siRNA, 10-30 pmol of fluorescein-siRNA (NEB) were used according to the manufacturer's instructions. Cells were then visualized, 24 and $48 \mathrm{~h}$ post transfection, in a conventional fluorescence microscope.

To evaluate the effective silencing of ER- $\alpha$ or ER- $\beta$, total proteins from transfected and non-transfected cells (controls) were extracted 24 and $48 \mathrm{~h}$ post transfection and ER- $\alpha$ or ER- $\beta$ expression was tested by western blot analysis as described above using TE111.5D11 specific monoclonal antibody and Y-19 specific polyclonal antibody respectively.

\section{Measurement of outer mitochondrial membrane integrity}

The integrity of outer mitochondrial membranes was evaluated using a commercially available kit from Sigma (CYTOC-OX1) according to the manufacturer's instructions. Briefly, mitochondrial fractions ( $2 \mu \mathrm{g}$ protein) were added to the assay buffer $(10 \mathrm{mM}$ Tris $-\mathrm{HCl}(\mathrm{pH} 7 \cdot 0)$ and $120 \mathrm{mM} \mathrm{KCl})$, in presence and absence of the detergent $n$-dodecyl $\beta$-D-maltoside. To these samples, $50 \mu \mathrm{l}$ reduced cytochrome $c(0 \cdot 22 \mathrm{mM})$ were added and changes in absorbance at $550 \mathrm{~nm}$ were monitored for $1 \mathrm{~min}$. An extinction coefficient of 21.84 was used. The results were expressed as percentage of mitochondria with damaged outer membrane.

\section{Mito Tracker red staining}

Coverslips with adherent cells were stained with MitoTracker red (Molecular Probes), which was prepared in dimethyl sulfoxide and then added to the cell culture medium at a final 
A

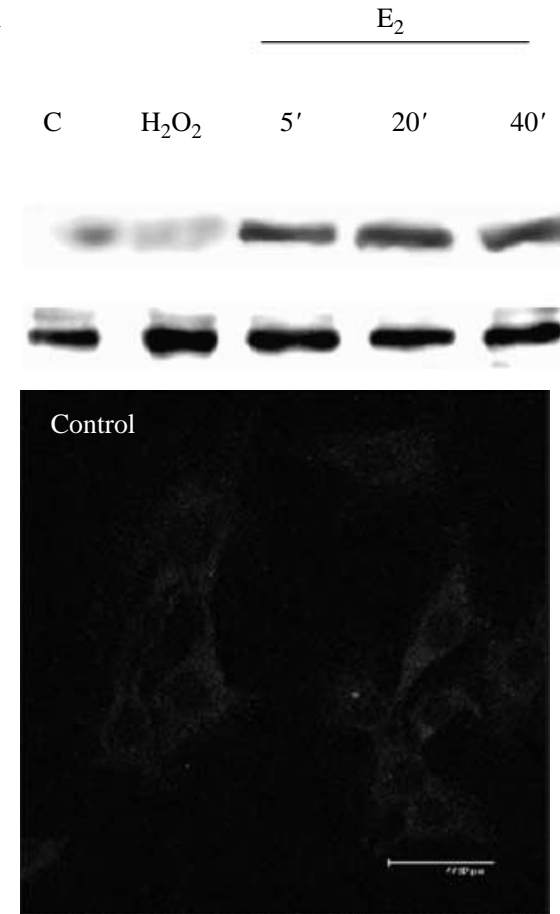

$\mathrm{H}_{2} \mathrm{O}_{2}$
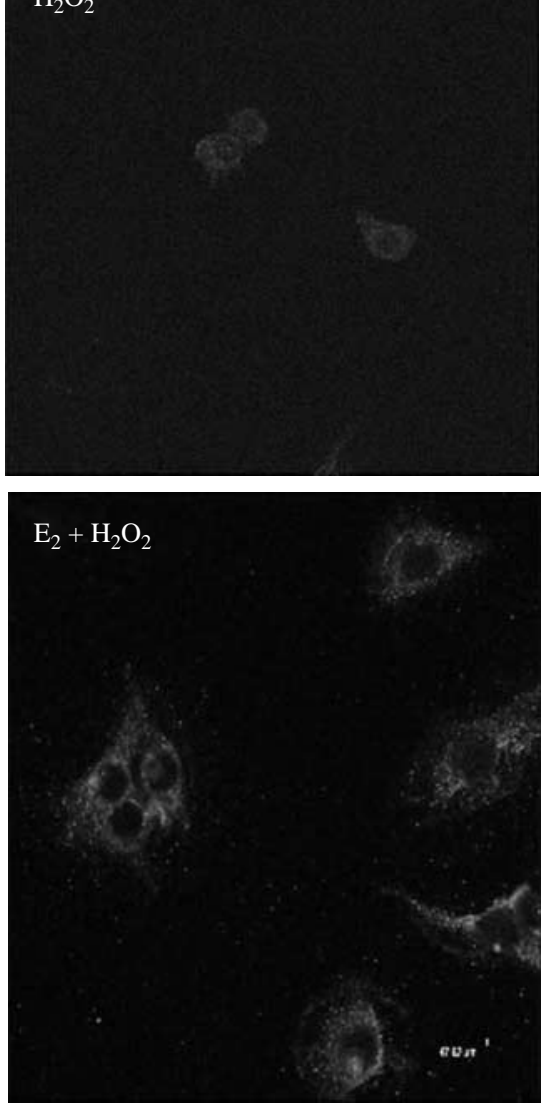

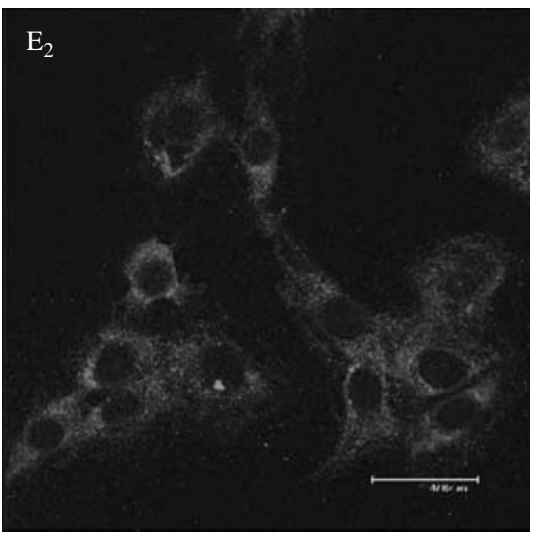

$\mathrm{E}_{2}+\mathrm{LY} 294002$ 
concentration of $1 \mu \mathrm{mol} / \mathrm{l}$. After $15-$ to $30-\mathrm{min}$ incubation at $37^{\circ} \mathrm{C}$, the cells were washed with PBS and fixed with methanol at $-20^{\circ} \mathrm{C}$ for $30 \mathrm{~min}$. Finally, the coverslips were analyzed by conventional and confocal fluorescence microscopy as described previously. Images were collected using a digital camera.

\section{Confocal microscopy}

The samples used for confocal microscopy were processed as described above and confocal scanning laser microscopy was performed with a Leica TCS SP2 AOBS microscope, using a $63 \times$ objective. The specificity of the labeling techniques was proven by the absence of labeling when the primary or the secondary antibodies were omitted.

\section{Statistical analysis}

Statistical treatment of the data was performed using the Student's $t$-test (Snedecor \& Cochran 1967). Data are means \pm s.D. of not less than three independent experiments. The data were considered statistical significant when $P<0 \cdot 05$.

\section{Results}

$E_{2}$ effects on $\mathrm{H}_{2} \mathrm{O}_{2}$ - or etoposide-induced apoptosis in C2C12 muscle cells

C2C12 myogenic cells were challenged with $0.5 \mathrm{mM} \mathrm{H}_{2} \mathrm{O}_{2}$ for $24 \mathrm{~h}$ and apoptotic events were investigated. The nuclear dye DAPI showed morphological changes typical of apoptosis such as nuclear fragmentation/condensation (pyknotic nuclei) after treatment with inducers, which represented $\sim 70 \%$ of the cultured muscle cells (Fig. 1). The same results were obtained by treating the $\mathrm{C} 2 \mathrm{C} 12$ cells with the semi-synthetic derivative of the podophyllotoxin etoposide $(25 \mu \mathrm{g} / \mathrm{ml})$ during $24 \mathrm{~h}$ (data no shown). Furthermore, $\mathrm{H}_{2} \mathrm{O}_{2}$ treatment resulted in DNA fragmentation in $\mathrm{C} 2 \mathrm{C} 12$ cells, as evidenced by the formation of a DNA ladder in agarose gels (Fig. 2), also providing evidence that exposure to $\mathrm{H}_{2} \mathrm{O}_{2}$ induces apoptosis in the muscle cells. Comparable results were obtained using etoposide (Fig. 2). Trypan blue staining excluded the possibility that these treatments induced necrosis of the cells (data not shown). On the other hand, we observed that treating C2C12 cells with $\mathrm{E}_{2}\left(10^{-8} \mathrm{M}\right)$ or with the synthetic non-steroidal analog DES $\left(10^{-8} \mathrm{M}\right)$ for $45 \mathrm{~min}$ prior to the apoptotic stimulus of $\mathrm{H}_{2} \mathrm{O}_{2}$, the percentage of apoptotic nuclei was significantly diminished (from $73 \%$ when the cells were treated with $\mathrm{H}_{2} \mathrm{O}_{2}$ alone to $\sim 8 \%$ when the cultures were preincubated with $\mathrm{E}_{2}$ before addition of $\left.\mathrm{H}_{2} \mathrm{O}_{2}\right)$. Similar values were obtained with etoposide (data not shown). In addition, DNA fragmentation induced by $\mathrm{H}_{2} \mathrm{O}_{2}$ or etoposide was abolished by the hormone treatment (Figs 1 and 2). The same results were obtained when the assays were performed in presence of DES (results not given).

The effects of $E_{2}$ and DES on the release of cytochrome $c$ due to loss of outer mitochondrial membrane integrity induced by $\mathrm{H}_{2} \mathrm{O}_{2}$ were evaluated by means of CYTOC-OX1 assays (see Materials and Methods). We observed that $70 \pm$ $1.5 \%$ of the cells presented damaged mitochondria after $\mathrm{H}_{2} \mathrm{O}_{2}$ treatment, whereas when the cultures were preincubated with $\mathrm{E}_{2}$ or DES before addition of $\mathrm{H}_{2} \mathrm{O}_{2}$, only $21 \pm 1 \cdot 2 \%$ or $10 \pm$ $0 \cdot 4 \%$ respectively, of the mitochondria were affected $(P<0 \cdot 05$; three independent experiments). In addition, morphological changes and cellular redistribution of mitochondria could be detected in $\mathrm{C} 2 \mathrm{C} 12$ cells treated with $\mathrm{H}_{2} \mathrm{O}_{2}$ as described above and stained with the fluorescent mitochondrial probe MitoTracker red. Thus, Fig. 3 shows that cells treated with vehicle (control) or $\mathrm{E}_{2}$ display 'spiderweb' or uniform distribution of mitochondria through the cytosol. On the other hand, when apoptosis was induced with $\mathrm{H}_{2} \mathrm{O}_{2}$, the cells showed reduced size 'pyknotic' mitochondria and characteristic clustering of the organelle around the nucleus (which represented $\sim 70 \%$ of the cultured muscle cells). These modifications could be prevented when the $\mathrm{C} 2 \mathrm{C} 12$ cells were incubated with $\mathrm{E}_{2}$ prior to treatment with $\mathrm{H}_{2} \mathrm{O}_{2}$ (Fig. 3). Likewise, Fig. 4 shows by western blot assays that both $\mathrm{H}_{2} \mathrm{O}_{2}$ and etoposide, under the same conditions as indicated before, induced the cleavage of PARP, whereas incubation with $\mathrm{E}_{2}\left(10^{-8} \mathrm{M}\right)$ for $45 \mathrm{~min}$ prior to the apoptotic stimuli abolished the cleavage of PARP.

\section{Activation of the PI3K/Akt pathway by $E_{2}$ in C2C12 muscle cells}

The ability of $\mathrm{E}_{2}$ to regulate the PI3K/Akt pathway in muscle cells was evaluated. This signaling pathway influences cell death through its direct effects on the phosphorylation state of BAD. $\mathrm{C} 2 \mathrm{C} 12$ cell cultures were incubated with the steroid hormone

\footnotetext{
Figure $517 \beta$-Estradiol induces phosphorylation of Akt. (A) $\mathrm{C} 2 \mathrm{C} 12$ cells were incubated with $10^{-8} \mathrm{M} \mathrm{E}_{2}$ for the indicated times or treated with $\mathrm{H}_{2} \mathrm{O}_{2}$ in the absence and presence of $\mathrm{E}_{2}$ with and without wortmannin as follows. Cell lysates were prepared and subjected to western blot analysis using an anti-phospho-Akt antibody. Total Akt levels were measured as protein loading control. C, untreated cells; $\mathrm{H}_{2} \mathrm{O}_{2}$, cells treated with $0.5 \mathrm{mM} \mathrm{H}_{2} \mathrm{O}_{2}$ during $24 \mathrm{~h} ; \mathrm{E}_{2}$, cells incubated with $10^{-8} \mathrm{M} 17 \beta$-estradiol for 5, 20, and $40 \mathrm{~min}$ or $8 \mathrm{~h} ; \mathrm{H}_{2} \mathrm{O}_{2}+\mathrm{E}_{2}$, cells preincubated with $10^{-8} \mathrm{M} 17 \beta$-estradiol for $45 \mathrm{~min}$ and then treated with $\mathrm{H}_{2} \mathrm{O}_{2}$ during $24 \mathrm{~h}$; Wort $+\mathrm{E}_{2}+\mathrm{H}_{2} \mathrm{O}_{2}$, cells were preincubated with wortmannin $(0 \cdot 1 \mu \mathrm{M}$ during $20 \mathrm{~min})$ and then with $17 \beta$-estradiol and $\mathrm{H}_{2} \mathrm{O}_{2}$ as before. $\mathrm{Mk}$, molecular weight colored marker. The blot is representative of three independent experiments with comparable results. (B) Confocal microscopy of Akt activation (phosphorylation). Phosphorylated Akt (green fluorescence) was stained by using anti-phospho-Akt antibody. Control, untreated cells; $\mathrm{E}_{2}$, cells incubated with $10^{-8} \mathrm{M} \mathrm{17 \beta -estradiol} \mathrm{for} 40 \mathrm{~min} ; \mathrm{H}_{2} \mathrm{O}_{2}$, cells treated with $0.5 \mathrm{mM} \mathrm{H}_{2} \mathrm{O}_{2}$ during $24 \mathrm{~h} ; \mathrm{E}_{2}+$ Ly294002, cells were preincubated with Ly294002 (25 $\mu \mathrm{M}$ during 20-30 min) and then treated whit $\mathrm{E}_{2}$ for $40 \mathrm{~min} . \mathrm{H}_{2} \mathrm{O}_{2}+\mathrm{E}_{2}$, cells preincubated with $10^{-8} \mathrm{M} 17 \beta$-estradiol for $45 \mathrm{~min}$ and then treated with $\mathrm{H}_{2} \mathrm{O}_{2}$ during $24 \mathrm{~h}$. Magnification: $63 \times$. Images are representative of at least three independent experiments.
} 


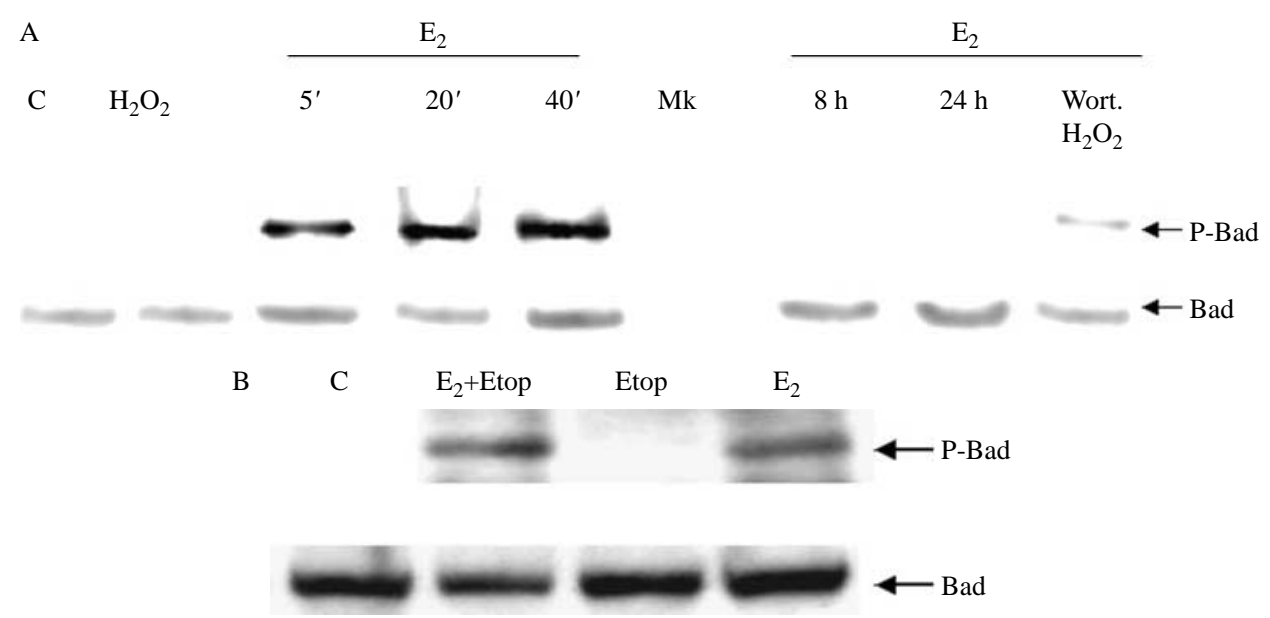

Figure $617 \beta$-Estradiol induces phosphorylation of BAD. C2C12 cells were treated with the indicated stimuli. (A) $\mathrm{C}$, untreated cells; $\mathrm{H}_{2} \mathrm{O}_{2}$, cells treated with $0.5 \mathrm{mM} \mathrm{H}_{2} \mathrm{O}_{2}$ during $40 \mathrm{~min}$; $\mathrm{E}_{2}$, cells incubated with $10^{-8} \mathrm{M}$ $17 \beta$-estradiol for 5, 20, and 40 min or 8 and $24 \mathrm{~h}$; Wort $+\mathrm{E}_{2}+\mathrm{H}_{2} \mathrm{O}_{2}$, cells were preincubated with wortmannin $(0 \cdot 1 \mu \mathrm{M}$ during $20 \mathrm{~min})$ and then with $17 \beta$-estradiol and $\mathrm{H}_{2} \mathrm{O}_{2}$ for $40 \mathrm{~min}$. Mk, molecular weight colored marker. (B) C, untreated cells; $E_{2}+$ Etop., cells were preincubated with $10^{-8} \mathrm{M} 17 \beta$-estradiol for $40 \mathrm{~min}$ and then with etoposide $(25 \mu \mathrm{g} / \mathrm{ml})$ during $1 \mathrm{~h}$; Etop., cells treated with etoposide during $1 \mathrm{~h}$; $\mathrm{E}_{2}$, cells were preincubated with $17 \beta$-estradiol for $40 \mathrm{~min}$. The cells were harvested and used to prepare cell lysates. The lysates were subjected to SDS-PAGE and blotted with anti-phospho-BAD (Ser 136) antibody. Actin levels were measured as protein loading control. The blot shown is representative of three independent experiments with comparable results.

$\left(10^{-8} \mathrm{M}\right)$ for various time intervals $(5,20$, and $40 \mathrm{~min}, 8 \mathrm{~h})$ followed by measurement of phospho-Akt levels. As shown in Fig. 5A, western blot analysis using anti-phospho-Akt (Ser 473) polyclonal antibody revealed Akt activation (phosphorylation) in response to $\mathrm{E}_{2}$. No appreciable changes in phosphorylation of Akt were induced by treatment with $0.5 \mathrm{mM} \mathrm{H}_{2} \mathrm{O}_{2}$ for $24 \mathrm{~h}$ as in the previous experiments. Of relevance, activation of Akt by the hormone was blocked when the cells were preincubated with the PI3K specific inhibitor wortmannin $(0 \cdot 1 \mu \mathrm{M}$ during $20 \mathrm{~min}$ ). Immunocytochemistry studies using confocal microscopy and the same antibody were congruent with the western blot results. Moreover, when the $\mathrm{C} 2 \mathrm{C} 12$ cells were preincubated with Ly294002 ( $25 \mu \mathrm{M}$ during 20-30 min), another PI3K inhibitor, and then treated with $\mathrm{E}_{2}$ as before, slight fluorescence was detected (Fig. 5B). These results demonstrate then that $\mathrm{E}_{2}$ is able to promptly activate Akt acting through PI3K.

\section{$E_{2}$ induces BAD phosphorylation in C2C12 muscle cells}

Next, we investigated the action of $\mathrm{E}_{2}$ on $\mathrm{BAD}$ phosphorylation, an event related to cell survival via the PI3K/Akt pathway. Figure 6 shows a marked increase in phosphorylation of $\mathrm{BAD}$ after 5-40 min treatment with $\mathrm{E}_{2}$, the effects being no longer detectable at 8 and $24 \mathrm{~h}$. Total BAD levels were unchanged during this treatment interval. As expected, in the presence of inducers of apoptosis, $\mathrm{H}_{2} \mathrm{O}_{2}$, or etoposide, phosphorylation of BAD was not observed (Fig. 6A and B). Co-treatments with $E_{2}$ and $\mathrm{H}_{2} \mathrm{O}_{2}$ or etoposide restored $\mathrm{BAD}$ phosphorylation (data not shown for $\left.\mathrm{H}_{2} \mathrm{O}_{2}\right)$. Wortmannin $(0 \cdot 1 \mu \mathrm{M})$ partially inhibited this recovery of the steroid hormone phosphorylation effect (Fig. 6A).

\section{Role of ERs in the antiapoptotic effects of $E_{2}$}

To address whether the antiapoptotic action of $\mathrm{E}_{2}$ on $\mathrm{C} 2 \mathrm{C} 12$ muscle cells is exerted through ERs, the above experiments on the effects of $\mathrm{E}_{2}$ on $\mathrm{H}_{2} \mathrm{O}_{2}$-induced cytochrome $c$ release were performed in presence of $1 \mu \mathrm{M}$ ICI 182780 , an ER antagonist. Figure 7 illustrates that the antagonist blocked the protective effect of the hormone. In addition, western blot assays showed that the inhibitory effect of $\mathrm{E}_{2}$ on $\mathrm{H}_{2} \mathrm{O}_{2}$-promoted apoptotic cleavage of PARP was almost totally abolished by ICI 182780 (Fig. 4). Also, we evaluated cytochrome $c$ release in C2C12 cells preincubated with specific antibodies against the ER isoforms $\alpha$ and (see Materials and Methods and legend to Fig. 7) followed by treatment with $10^{-8} \mathrm{M} \mathrm{E}_{2}$ for 45 min and finally challenged with $0.5 \mathrm{mM} \mathrm{H}_{2} \mathrm{O}_{2}$ during $24 \mathrm{~h}$. Under these conditions, inhibition of $\mathrm{H}_{2} \mathrm{O}_{2}$-induced cytochrome $c$ release by $\mathrm{E}_{2}$ (or DES) was reduced (Fig. 7). Thus, polyclonal anti-ER- $\beta$ antibodies L-20 (mapping near C-terminus) and Y-19 (mapping at the $\mathrm{N}$-terminus) abolished it by $66 \%$ the antiapoptotic effect of $\mathrm{E}_{2}$, whereas monoclonal ER- $\alpha$ antibody Ab-10 (against ER ligand binding domain) suppressed it by $40 \%$. Appropriate controls allowed to exclude nonspecific effects due to the permeabilization treatment and/or antibody incubation (see condition 'ANTIBODY' in Fig. 7).

To strengthen the above evidence involving ER- $\beta$ and possibly ER -, we evaluated cytochrome $c$ release in $\mathrm{C} 2 \mathrm{C} 12$ cells transfected with specific siRNAs to induce silencing of 


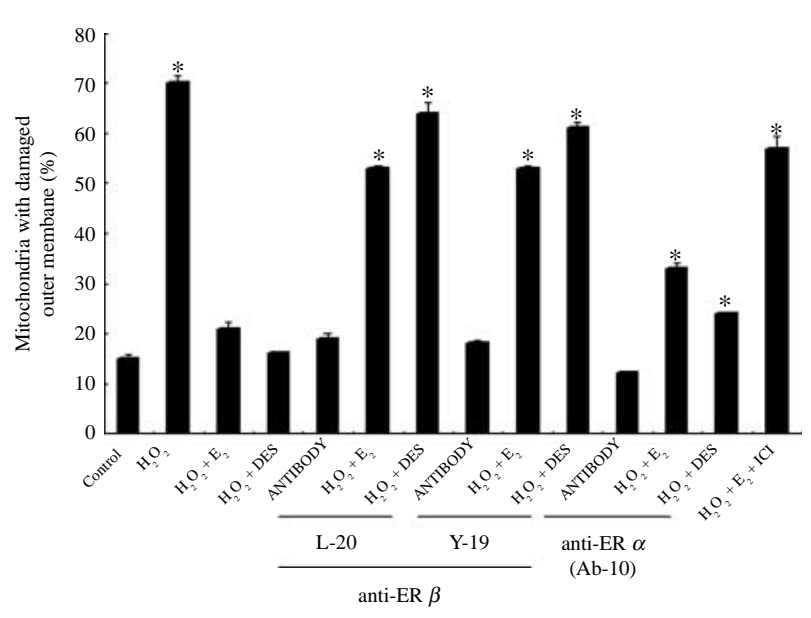

Figure 7 Antibodies against the estrogen receptor (ER) isoforms $\alpha$ and $\beta$ block $17 \beta$-estradiol inhibition of $\mathrm{H}_{2} \mathrm{O}_{2}$-induced cytochrome $c$ release in muscle cells. $\mathrm{C} 2 \mathrm{C} 12$ muscle cells were permeabilized and then incubated with specific antibodies against the isoforms (L-20, 1:200 or Y-19, 1:100) or (Ab-10/clone TE111.5D11, 1:400) of ER as described under Materials and Methods, then treated with $10^{-8} \mathrm{M} 17 \beta$-estradiol or DES for $45 \mathrm{~min}$ and finally challenged with $0.5 \mathrm{mM} \mathrm{H}_{2} \mathrm{O}_{2}$ during $24 \mathrm{~h}$. Cytochrome $c$ release was measured as described under Materials and Methods. Control, untreated cells; $\mathrm{H}_{2} \mathrm{O}_{2}$, cells treated with $0.5 \mathrm{mM} \mathrm{H} \mathrm{O}_{2}$ during $24 \mathrm{~h} ; \mathrm{H}_{2} \mathrm{O}_{2}+\mathrm{E}_{2}$, cells preincubated with $10^{-8} \mathrm{M} 17 \beta$-estradiol for $45 \mathrm{~min}$ and then treated with $0.5 \mathrm{mM} \mathrm{H}_{2} \mathrm{O}_{2}$ during $24 \mathrm{~h} ; \mathrm{H}_{2} \mathrm{O}_{2}+$ DES, cells preincubated with $10^{-8} \mathrm{M}$ DES for $45 \mathrm{~min}$ and then treated with $0.5 \mathrm{mM} \mathrm{H}_{2} \mathrm{O}_{2}$ during $24 \mathrm{~h}$; ANTIBODY, cells were only permeabilized in presence of the indicated antibody without further treatment. $\mathrm{ICl}+\mathrm{E}_{2}+\mathrm{H}_{2} \mathrm{O}_{2}$, cells preincubated with $1 \mu \mathrm{M} \mathrm{ICl}$ 182780 for 45 min and then with $17 \beta$-estradiol and $\mathrm{H}_{2} \mathrm{O}_{2}$ as before. Each value represents the mean of three independent determinations \pm s.D. ${ }^{*} P<0 \cdot 05$ with respect to the control.

each ER isoform. Optimum transfection conditions were established using fluorescein-siRNA (NEB; $\geq 70 \%$ after $24-\mathrm{h}$ incubation with $20 \mathrm{pmol}$ of fluorescent probe; Fig. 8A). To verify the silencing efficiency and specificity of siRNA effects, we examined by western blot analysis the expression levels of ER- $\alpha$ and ER- $\beta$ after transfection with isoformselective siRNAs (24/48 h with $10 / 20$ pmol of ER- $\alpha$ or ER- $\beta$ siRNA (NEB)). Figure $8 B$ indicates that each siRNA probe led to a significant suppression in the levels of the corresponding protein. Under these conditions, ER- $\beta$ silencing caused a significant blockade $(\sim 78 \% \pm 2 \cdot 5)$ of $\mathrm{E}_{2}$ effects on cytochrome $c$ liberation, whereas ER- $\alpha$ silencing induced a minor reduction of $E_{2}$ effects $(\sim 30 \% \pm 0 \cdot 7)$. The siRNAs used are highly specific. We used the fluorescent probe of the kit (chemically synthesized 21 bp RNA which has no sequence identity to any mammalian sequences) and differently to siRNA $\alpha$ or $\beta$ no blockage was observed (not shown). These pieces of evidence show that $\mathrm{E}_{2}$ inhibition of cytochrome $c$ release is mediated mainly by ER- $\beta$ (Fig. $8 \mathrm{C}$ ). On the other hand, transfection of $\mathrm{C} 2 \mathrm{C} 12$ cells with either ER- $\alpha$ siRNA or ER- $\beta$ siRNA blocked the activation of $A k t$ by $E_{2}$ shown before (Fig. $5 \mathrm{~A}$ ), revealing that both receptor isoforms mediate this step (Fig. 8D).

\section{Discussion}

$\mathrm{E}_{2}$ can sustain survival or alternatively induce apoptosis of cells depending on their biological context (Choi et al. 2001, Okasha et al. 2001, Florian \& Magder 2008, Seli et al. 2007). The data obtained in this work using the well-characterized myogenic C2C12 murine cell line provides evidence that the estrogen at physiological concentrations inhibits apoptosis of skeletal muscle cells. As experimental approach, the C2C12 cells were led into apoptosis by exposure to $\mathrm{H}_{2} \mathrm{O}_{2}$ or etoposide, state which was first evidenced by the results of DAPI staining and DNA laddering. Under these conditions, we observed that the cells preincubated with $\mathrm{E}_{2}\left(10^{-8} \mathrm{M}\right)$, similarly as the synthetic nonsteroidal analog DES $\left(10^{-8} \mathrm{M}\right)$, block the effects of hydrogen peroxide or etoposide on the number of apoptotic nuclei and DNA fragmentation. This protective action of the hormone was dose dependent between $10^{-6}$ and $10^{-10} \mathrm{M}$, maximal effects being detected at $10^{-8} \mathrm{M}$ (not shown), in agreement with saturation binding analysis data of the ER in C2C12 cells (Milanesi, de Boland and Boland submitted), an observation which may be related to the participation of ER as mediator of the antiapoptotic action $\mathrm{E}_{2}$ in muscle cells demonstrated in the present investigations (see below). This concentration of estrogen has been shown to inhibit apoptosis in other cell types (Fernando \& Wimalasena 2004). Although $\mathrm{E}_{2}$ is known to induce mitogenic effects, the fact that no difference in the number of apoptotic nuclei between the $E_{2}$ and control conditions was observed indicates that the steroid exerts mainly an apoptotic action rather than a mitogenic one in C2C12 cells.

The mitochondria play a central role in apoptosis. Within the past few years, their participation in the control of apoptosis has been well documented. Morphological changes and cellular redistribution of mitochondria in apoptotic cells are known to occur (Desagher \& Martinou 2000). The mitochondrial protein cytochrome $c$ plays a key role in apoptosis (reviewed by Jiang \& Wang 2004). This soluble protein is localized in the intermembrane space and loosely attached to the surface of the inner mitochondrial membrane. In response to a variety of apoptosis-inducing agents, cytochrome $c$ is released from mitochondria to the cytosol (Liu et al. 1996, Reed 1997). The necessary event for cytochrome $c$ release to take place is the loss of integrity of the outer mitochondrial membrane (Crompton et al. 1998, Green \& Kroemer 2004). Evaluation of the outer membrane state by the determination of cytochrome $c$ oxidase activity represents a useful indicator of cytochrome $c$ release. The inhibition of $\mathrm{H}_{2} \mathrm{O}_{2}$-induced cytochrome $c$ release by $\mathrm{E}_{2}$ or DES observed in this study, like the effects of hormone on the size and cytosolic distribution of mitochondria, suggests a protective effect of $E_{2}$ and its analog on this organelle.

Several interpretations may apply regarding the physiological relevance of the morphological changes and redistribution of the organelle in response to $\mathrm{H}_{2} \mathrm{O}_{2}$ treatment. It is possible that clustering of mitochondria near the nucleus generates high energy levels required to maintain the machinery triggered by the apoptotic stimulus active. 


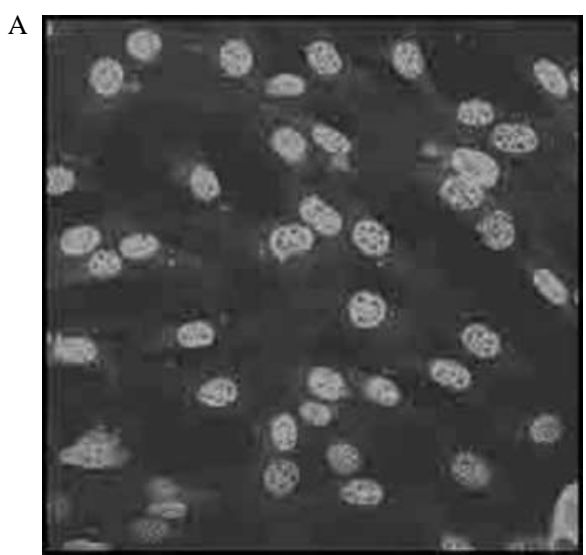

B

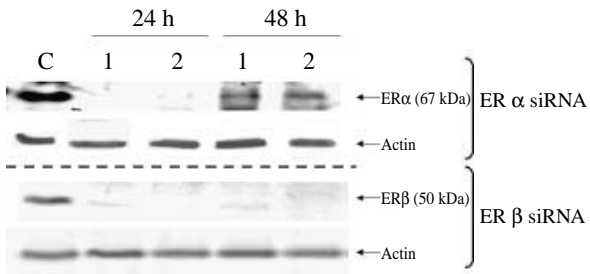

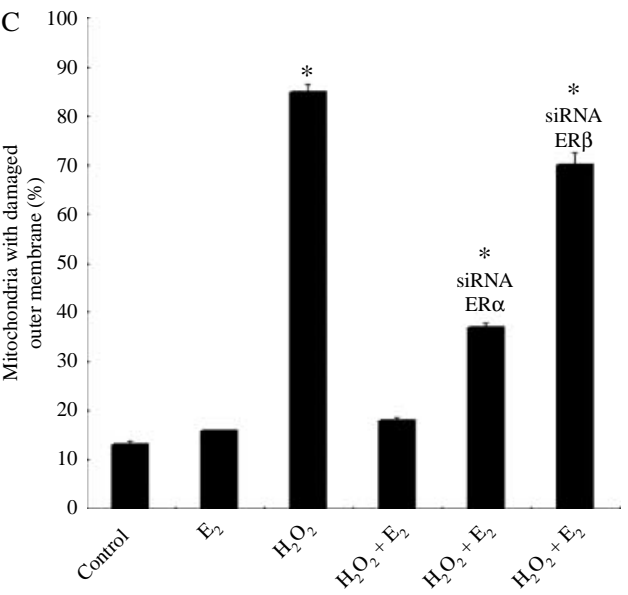

$\mathrm{D}$

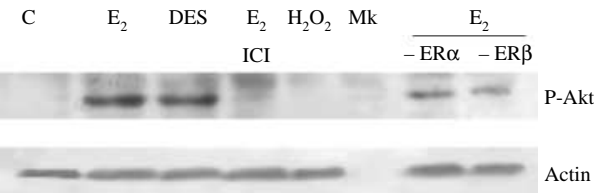

Figure 8 Silencing of ER isoforms inhibits the effects of $17 \beta$-estradiol on cytochrome $c$ release and Akt activation. Transfections of $\mathrm{C} 2 \mathrm{C} 12$ cells with siRNAs were performed as described under Materials and Methods. (A) Transfection efficiency of siRNA was estimated using fluorescein-siRNA transfection control and TransPass R2 transfection reagent. Cells were then visualized in a conventional microscope employing an adequate filter for green fluorescence. A typical pattern of fluorescence with fluorescein-siRNA is shown (more of $70 \%$ cells present green fluorescence). Original magnification $=400 \times$. (B) C2C12 cells were transiently transfected with two concentrations of ER- $\alpha$ siRNA (NEB; upper panel) or ER- $\beta$ siRNA (NEB; lower panel). Expression of ER isoforms was analyzed 24 and $48 \mathrm{~h}$ post transfection by western blot analysis as described in Materials and Methods. Immunoblots of total cell lysates employing TE111.5D11 monoclonal antibody anti-ER- $\alpha$ or Y-19 specific polyclonal antibody anti-ER- $\beta$ are shown. C, control; 1,10 pmol of siRNA; 2, 20 pmol of siRNA. Actin loading control was detected using anti-actin polyclonal antibody. A representative blot from two independent experiments is shown. (C) C2C12 cells were transfected with ER$\alpha$ siRNA (NEB) or ER- $\beta$ siRNA (NEB) and then cytochrome $c$ release was measured as Fig. 7. Control, untreated cells; $E_{2}$, cells treated with $10^{-8} \mathrm{M} 17 \beta$-estradiol for $24 \mathrm{~h} ; \mathrm{H}_{2} \mathrm{O}_{2}$, cells treated with $0.5 \mathrm{mM} \mathrm{H} \mathrm{H}_{2} \mathrm{O}_{2}$ during $24 \mathrm{~h} ; \mathrm{H}_{2} \mathrm{O}_{2}+\mathrm{E}_{2}$, cells preincubated with $10^{-8} \mathrm{M} 17 \beta$-estradiol for $45 \mathrm{~min}$ and then treated with $0.5 \mathrm{mM} \mathrm{H}_{2} \mathrm{O}_{2}$ during $24 \mathrm{~h} ; \mathrm{H}_{2} \mathrm{O}_{2}$ Each value represents the mean of three independent determinations \pm s.D. $* P<0.05$ with respect to the control. (D) C2C12 cells were transfected with ER- $\alpha$ siRNA (NEB) or ER- $\beta$ siRNA (NEB) and Akt activation was evaluated as in Fig. 5A. C, untreated cells; $E_{2}$, cells incubated with $10^{-8} \mathrm{M} 17 \beta-$ estradiol for $40 \mathrm{~min}$; DES, cells incubated with $10^{-8} \mathrm{M}$ DES for $40 \mathrm{~min} ; \mathrm{ICI}+\mathrm{E}_{2}$, cells preincubated with $1 \mu \mathrm{M} \mathrm{ICl} 182780$ for $45 \mathrm{~min}$ and then treated with $10^{-8} \mathrm{M} 17 \beta$-estradiol for $40 \mathrm{~min} ; \mathrm{H}_{2} \mathrm{O}_{2}$, cells treated with $0.5 \mathrm{mM} \mathrm{H}_{2} \mathrm{O}_{2}$ during $24 \mathrm{~h}$; $\mathrm{Mk}$, molecular weight colored marker; ER- $\alpha$, cells transfected with ER- $\alpha$ siRNA and treated with $10^{-8} \mathrm{M} 17 \beta$-estradiol for $40 \mathrm{~min}$; ER- $\beta$, cells transfected with ER- $\beta$ siRNA and treated with $10^{-8}$ M $17 \beta$-estradiol for $40 \mathrm{~min}$. The blot is representative of three independent experiments with comparable results.

Also, displacement of the organelle could facilitate translocation of mitochondrial proteins, such as apoptosis-inducing factor (AIF) which binds to DNA and triggers its destruction, to the nucleus (Susin et al. 2000). Moreover, the modifications that undergo mitochondria like size reduction or pyknosis could be related to the release of mitochondrial proteins (e.g., AIF, cytochrome c) observed in apoptosis (Granville et al. 2001). Further studies are necessary to elucidate the relative role of these events and the mechanisms by which estrogens exert an inhibitory effect upon them.

Another prominent episode during apoptosis is the selective cleavage of PARP by caspases (Lazebnik et al.
1994), which is a universal event observed during programed cell death induced by a variety of apoptotic stimuli. Here, we evidenced that the hormone inhibits $\mathrm{H}_{2} \mathrm{O}_{2}$-promoted apoptotic cleavage of PARP. This effect was almost totally abolished by ICI 182780 indicating that the antiapoptotic action of $\mathrm{E}_{2}$ is mediated by the ER.

As mentioned in Introduction, the lipid kinase PI3K as well as its downstream target Akt regulates a diverse array of cellular events (Cross et al. 2000, Brazil \& Hemmings 2001) and both have been implicated in cellular survival and apoptosis (O'Groman et al. 2000, Xu et al. 2003, Grutzner et al. 2006). In addition, it has been reported that $\mathrm{E}_{2}$ modulates the PI3K/Akt 
signaling pathway in various cell types (Simoncini et al. 2000, Lee et al. 2005, Guo et al. 2006). Mediation by PI3K and Akt of the antiapoptotic action of estrogen in $\mathrm{C} 2 \mathrm{C} 12$ cells was first shown by experiments with Mitotracker and DAPI stains to observe mitochondrial morphology and apoptotic nuclei respectively, which showed that PI3K inhibitors wortmannin or LY294002 abolished the effects of $E_{2}$ on cell survival under apoptotic conditions (data not presented in Results). The participation of $A k t$ in the effects of $E_{2}$ was further evidenced by western blot and immunocytochemistry assays, revealing a rapid and sustained activation (phosphorylation) of Akt in response to $\mathrm{E}_{2}$, the latter in accord with the fact that prolonged activity of Akt is required to maintain BAD inactive (Fernando \& Wimalasena 2004). Suppression of $E_{2}$ effects on Akt by wortmannin and LY940022 implies a role for PI3K/Akt in the antiapoptotic effects of the hormone in $\mathrm{C} 2 \mathrm{C} 12$ cells. Additional studies are required to identify the targets of this pathway in $\mathrm{C} 2 \mathrm{C} 12$ cells and then clarify the significance of estrogen action on apoptosis of skeletal muscle cells.

Phosphorylated BAD is devoid of its apoptotic activity, since it is sequestered away from the site of action in the mitochondria by binding to cytosolic 14-3-3 proteins (Datta et al. 1997, Yano et al. 1998). BAD can be phosphorylated on serine 136 by Akt (Datta et al. 1997) and since the hormone activated Akt in C2C12 cells, the ability of the steroid to induce this phosphorylation was investigated using a phosphospecific antibody. We found that $E_{2}$ rapidly induces phosphorylation of $\mathrm{BAD}$ without altering $\mathrm{BAD}$ protein levels, suggestive of activation of non-genomic signal pathways. Also we observed that phosphorylation of BAD is partially affected when the cells were preincubated with the PI3K inhibitor wortmannin. Since the effects of $E_{2}$ on Akt persist for longer time intervals, it is then possible that $\mathrm{PI} 3 \mathrm{~K} / \mathrm{Akt}$ and $\mathrm{BAD}$ could be involved as genomic as well as non-genomic mediators of the antiapoptotic actions of the steroid. Further investigations are required to clarify this aspect.

Altogether these data strongly suggest that $E_{2}$ exerts antiapoptotic actions in skeletal muscle cells through inactivation of proapoptotic BAD protein as a consequence of Akt activation by PI3K. Since wortmannin was unable to totally inhibit the effect of $\mathrm{E}_{2}$, the possibility that more than one kinase participates in $\mathrm{E}_{2}$-induced $\mathrm{BAD}$ phosphorylation cannot be excluded.

As the protective effect of $E_{2}$ at the mitochondrial level (cytochrome $c$ release) was inhibited in presence of specific anti ER - or ER - antibodies or using siRNA for each isoform, we conclude that it is dependent on ER activation. Regarding the use of antibodies, equivalent concentrations were used for each isoform, and well in excess. These conditions as well as the time of incubation used ensure that all binding sites were blocked. The antibodies are highly specific and preclude cross-reaction between the two isoforms. The fact that inhibition of the hormone protective action on mitochondria was more evident immunoblocking or suppressing ER- $\beta$ than ER - suggests that the $\beta$ isoform of the receptor mediates the antiapoptotic effects of $\mathrm{E}_{2}$ at this site of action to a greater extent than the $\alpha$ isoform. This could be the consequence of greater abundance of this isoform in our cell system or due to the fact that ER- $\beta$ localizes in mitochondria in $\mathrm{C} 2 \mathrm{C} 12$ cells (data not shown). This hypothesis is in agreement with evidence showing that relative receptor abundance of each isoform varies depending on the cellular type; e.g., in MCF-7 ER- $\beta$ is considerably less abundant than ER- $\alpha$ and, interestingly, this small amount of ER- $\beta$ is concentrated in mitochondria (Pedram et al. 2006).

In summary, this study shows that $\mathrm{E}_{2}$ inhibits $\mathrm{H}_{2} \mathrm{O}_{2}$ or etoposide-induced apoptosis in skeletal muscle cells acting at least at two different levels. One of them is inducing PI3K/Akt activation and then BAD phosphorylation, process in which both isoforms of the ER participate. The other relates to a protective effect of mitochondria integrity and involves mainly ER- $\beta$, suggested by the inhibition of $E_{2}$ effects on cytochrome $c$ release upon ER isoform silencing.

Estrogen signaling and cell survival have been investigated in other cell types, revealing similar and/or additional features with respect to the mechanism of signal transduction shown here for the antiapoptotic action of $\mathrm{E}_{2}$ in $\mathrm{C} 2 \mathrm{C} 12$ skeletal muscle cells. Thus, there are data demonstrating that $\mathrm{E}_{2}$ increases activation of Akt improving survival and decreasing apoptosis in murine cardiomyocytes both in vivo and in vitro by ER - and PI3K-Aktdependent pathways (Patten et al. 2004), similarly to C2C12 cells. Moreover, $\mathrm{E}_{2}$ abrogates apoptosis in MCF-7 breast cancer cells $(\mathrm{ER}+)$ through inactivation of BAD: Ras-dependent nongenomic pathways requiring signaling through ERK and Akt (Fernando \& Wimalasena 2004); however, the participation of the ER was not studied. ER- $\alpha$ and ER- $\beta$ have been detected in the mitochondria of MCF-7 breast cancer cells and endothelial cells and involved in $\mathrm{E}_{2}$-induced direct inhibition of mitochondrial ROS formation and cytochrome $c$ release, events leading to apoptotic cell death (Pedram et al. 2006). Interestingly, we have found $\mathrm{ER}-\beta$ predominantly in mitochondria of $\mathrm{C} 2 \mathrm{C} 12$ cells (data not shown). On the other hand, it has been reported that $E_{2}$ prevents chemotherapy or radiation-induced apoptosis in these tumorogenic breast cells through plasma membraneassociated ERs (Razandi et al. 2000). In cancer cell lines containing transfected ERs, there is evidence that the $\mathrm{E}_{2}-\mathrm{ER}-\alpha$ complex rapidly activates multiple signal transduction pathways (i.e., PI3K/Akt, ERK/MAPK) committed to apoptotic cascade prevention (Acconcia et al. 2005), whereas, on the contrary, $E_{2}$ can enhance antiapoptotic activity via ER- $\beta$ during oxidative damage in hepatocytes (Inoue et al. 2003). Also, in osteocyte bone cells estrogens attenuate apoptosis by activating ERKs through extranuclear ERs (Plotkin et al. 2005).

Clearly, additional studies are then necessary to further elucidate the signaling mechanisms which mediate the antiapoptotic action of $E_{2}$ in skeletal muscle cells. This knowledge may be of relevance to develop therapies for prevention and treatment of sarcopenia associated with estrogen-deficit states.

\section{Acknowledgements}

This research was supported by grants from the Agencia Nacional de Promoción Científica y Tecnológica (ANPCyT) 
and Consejo Nacional de Investigaciones Científicas y Técnicas (CONICET), Argentina. Andrea Vasconsuelo is a recipient of a postdoctoral research fellowship from ANPCyT. Lorena Milanesi and Ricardo Boland are members of CONICET Investigator Career. The authors declare that there is no conflict of interest that would prejudice the impartiality of this scientific work.

\section{References}

Acconcia F, Totta P, Ogawa S, Cardillo I, Inoue S, Leone S, Trentalance A, Muramatsu M \& Marino M 2005 Survival versus apoptotic $17 \beta$-estradiol effect: role of ER $\alpha$ and ER $\beta$ activated non-genomic signalling. Journal of Cellular Physiology 203 193-201.

Beato M, Truss M \& Chavez S 1996 Control of transcription by steroid hormones. Annals of the New York Academy of Sciences 278 93-123.

Biswas G, Guha M \& Avadhani NG 2005 Mitochondria-to-nucleus stress signaling in mammalian cells: nature of nuclear gene targets, transcription regulation, and induced resistance to apoptosis. Gene 354 132-139.

Bjornstrom L \& Sjoberg M 2005 Mechanisms of estrogen receptor signaling: convergence of genomic and nongenomic actions on target genes. Molecular Endocrinology 19 833-842.

Bradford M 1976 A rapid and sensitive method for the quantitation of microgram quantities of protein utilizing the principle of protein-dye binding. Analytical Biochemistry 72 248-254.

Brazil DP \& Hemmings BA 2001 Ten years of protein kinase B signalling: a hard Akt to follow. Trends in Biochemical Sciences 26 657-664.

Choi KC, Kang SK, Tai CJ, Auersperg N \& Leung PC 2001 Estradiol up-regulates antiapoptotic $\mathrm{Bcl}-2$ messenger ribonucleic acid and protein in tumorigenic ovarian surface epithelium cells. Endocrinology 142 2351-2360.

Coffer P, Jin J \& Woodgett JR 1998 Protein kinase B (c-Akt): a multifunctional mediator of phosphatidylinositol 3-kinase activation. Biochemical Journal 335 1-13.

Crompton M, Virji S \& Ward JM 1998 Cyclophilin-D binds strongly to complexes of the voltage-dependent anion channel and the adenine nucleotide translocase to form the permeability transition pore. European Journal of Biochemistry 258 729-735.

Cross TG, Scheel-Toellner D, Henriquez NV, Deacon E, Salmon M \& Lord JM 2000 Serine/threonine protein kinases and apoptosis. Experimental Cell Research 256 34-41.

Datta SR, Dudek H, Tao X, Masters S, Fu H, Gotoh Y \& Greenberg ME 1997 Akt phosphorylation of BAD couples survival signals to the cellintrinsic death machinery. Cell 91 231-241.

Desagher S \& Martinou JC 2000 Mitochondria as the central control point of apoptosis. Trends in Cell Biology 1 369-377.

Dionne IJ, Kinaman KA \& Poehlman ET 2000 Sarcopenia and muscle function during menopause and horrmone-replacement therapy. Journal of Nutrition, Health and Aging 4 156-161.

Evans RM 1988 The steroid and thyroid hormone receptor superfamily. Science 240 889-895.

Fernando RI \& Wimalasena J 2004 Estradiol abrogates apoptosis in breast cancer cells through inactivation of BAD: ras-dependent nongenomic pathways requiring signaling through ERK and Akt. Molecular Biology of the Cell 7 3266-3284.

Florian M \& Magder S 2008 Estrogen decreases TNF- $\alpha$ and oxidized LDl induced apoptosis in endothelial cells. Steroids In press.

Granville DJ, Cassidy BA, Ruehlmann DO, Choy JC, Brenner C, Kroemer G, van Breemen C, Margaron P, Hunt DW \& McManus BM 2001 Mitochondrial release of apoptosis-inducing factor and cytochrome $c$ during smooth muscle cell apoptosis. American Journal of Pathology 159 305-311.

Green DR \& Kroemer G 2004 The pathophysiology of mitochondrial cell death. Science 5684 626-629.
Grutzner U, Keller M, Bach M, Kiemer AK, Meissner H, Bilzer M, Zahler S, Gerbes AL \& Vollmar AM 2006 PI3-kinase pathway is responsible for antiapoptotic effects of atrial natriuretic peptide in rat liver transplantation. World Journal of Gastroenterology 7 1049-1055.

Guo R, Wei LH, Tu Z, Sun PM, Wang JL, Zhao D, Li X \& Tang J 2006 17ßEstradiol activates PI3K/Akt signaling pathway by estrogen receptor (ER)dependent and ER-independent mechanisms in endometrial cancer cells. Journal of Steroid Biochemistry and Molecular Biology 99 9-18.

Hall JM, Couse JF \& Korach KS 2001 The multifaceted mechanisms of estradiol and estrogen receptor signaling. Journal of Biological Chemistry 276 36869-36872.

Hewitt SC \& Korach KS 2002 Estrogen receptors: structure, mechanisms and function. Reviews in Endocrine and Metabolic Disorders 3 193-200.

Horvat A, Nikezíc G, Petrovíc S \& Kanazir DT 2001 Binding of estradiol to synaptosomal mitochondria: physiological significance. Cellular and Molecular Life Sciences 58 636-644.

Huppertz B, Tews DS \& Kaufmann P 2001 Apoptosis and syncytial fusion in human placental trophoblast and skeletal muscle. International Review of Cytology 205 215-253.

Inoue $\mathrm{H}$, Shimizu I, Lu G, Itonaga M, Cui X, Okamura Y, Shono M, Hona H, Inoue S, Muramatsu M et al. 2003 Idoxifene and estradiol enhance antiapoptotic activity through estrogen receptor $\beta$ in cultured rat hepatocytes. Digestive Diseases and Sciences $\mathbf{4 8}$ 570-580.

Jiang X \& Wang X 2004 Cytochrome $c$-mediated apoptosis. Annual Review of Biochemistry 73 87-106.

Jiang B, Xiao W, Shi Y, Liu M \& Xiao X 2005a Role of Smac/DIABLO in hydrogen peroxide-induced apoptosis in $\mathrm{C} 2 \mathrm{C} 12$ myogenic cells. Free Radical Biology and Medicine 39 658-667.

Jiang B, Xiao W, Shi Y, Liu M \& Xiao X 2005b Heat shock pretreatment inhibited the release of Smac/DIABLO from mitochondria and apoptosis induced by hydrogen peroxide in cardiomyocytes and C2C12 myogenic cells. Cell Stress and Chaperones Autumn. 10 252-262.

Kahlert S, Grohe C, Karas RH, Lobbert K, Neyses L \& Vetter H 1997 Effects of estrogen on skeletal myoblast growth. Biochemical and Biophysical Research Communications 232 373-378.

Kavurma MM \& Khachigian LM 2003 Sp1 inhibits proliferation and induces apoptosis in vascular smooth muscle cells by repressing p21WAF1/Cip1 transcription and cyclin D1-Cdk4-p21WAF1/Cip1 complex formation. Journal of Biological Chemistry 278 32537-32543.

Laemmli UK 1970 Cleavage of structural proteins during the assembly of the head of bacteriophage T4. Nature 227 680-685.

Lazebnik YA, Kaufmann SH, Desnoyers S, Poirier GG \& Earnshaw WC 1994 Cleavage of poly(ADP-ribose) polymerase by a proteinase with properties like ICE. Nature 371 346-347.

Lee YR, Park J, Yu HN, Kim JS, Youn HJ \& Jung SH 2005 Up-regulation of PI3K/Akt signaling by 17beta-estradiol through activation of estrogen receptor-alpha, but not estrogen receptor-beta, and stimulates cell growth in breast cancer cells. Biochemical and Biophysical Research Communications 4 1221-1226.

Lemoine S, Granier P, Tiffoche C, Rannou-Bekono F, Thieulant ML \& Delamarche P 2003 Estrogen receptor alpha mRNA in human skeletal muscles. Medicine and Science in Sports and Exercise 35 439-443.

Li L, Haynes MP \& Bender JR 2003 Plasma membrane localization and function of the estrogen receptor -variant (ER 46) in human endothelial cells. PNAS 100 4807-4812.

Liu X, Kim CN, Yang J, Jemmerson R \& Wang X 1996 Induction of apoptotic program in cell-free extracts: requirement for dATP and cytochrome c. Cell 86 147-157.

Luconi M, Muratori M, Forti G \& Baldi E 1999 Identification and characterization of a novel functional estrogen receptor on human sperm membrane that interferes with progesterone effects. Journal of Clinical Endocrinology and Metabolism 84 1670-1678.

Mizumoto K, Rothman RJ \& Farber JL 1994 Programmed cell death (apoptosis) of mouse fibroblasts is induced by the topoisomerase II inhibitor etoposide. Molecular Pharmacology 46 890-895.

Monje P \& Boland R 1999 Characterization of membrane estrogen binding sites from rabbit uterus. Molecular and Cellular Endocrinology 147 75-84. 
Monje P \& Boland R 2001 Subcellular distribution of native estrogen receptor $\boldsymbol{\alpha}$ and $\beta$ isoforms in rabbit uterus and ovary. Journal of Cellular Biochemistry $\mathbf{8 2}$ 467-479.

Monje P \& Boland R 2002 Expression and cellular localization of naturally ocurring beta estrogen receptors in uterine and mammary cell lines. Journal of Cellular Biochemistry 86 136-144.

Monje P, Zanello S, Holick M \& Boland R 2001 Differential cellular localization of estrogen receptor $\alpha$ in uterine and mammary cells. Molecular and Cellular Endocrinology 181 117-129.

Muldoon TG, Watson GH, Craig EA \& Steinsapir J 1988 Microsomal receptor for steroid hormones: functional implications for nuclear activity. Journal of Steroid Biochemistry 30 23-31.

Norfleet AM, Clarke CH, Gametchu B \& Watson CS 2000 Antibodies to the estrogen receptor- $\alpha$ modulate rapid prolactin release form rat pituitary tumor cells through plasma membrane estrogen receptors. FASEB Journal 14 157-165

O'Groman DM, McKenna SL, McGahon AJ, Knox KA \& Cotter TG 2000 Sensitation of HL60 human leukemic cells to cytotoxic drug-induced apoptosis by inhibition of PI3-kinase survival signals. Leukemia 14 602-611.

Okasha SA, Ryu S, Do Y, McKallip RJ, Nagarkatti M \& Nagarkatti PS 2001 Evidence for estradiol-induced apoptosis and dysregulated $\mathrm{T}$ cell maturation in the thymus. Toxicology 163 49-62.

Osaki M, Oshimura M \& Ito H 2004 PI3K-Akt pathway: its functions and alterations in human cancer. Apoptosis 9 667-676.

Parikh I, Anderson WL \& Neame P 1980 Identification of high affinity estrogen binding sites in calf uterine microsomal membranes. Journal of Biological Chemistry 255 10266-10270.

Patten RD, Pourati I, Aronovitz MJ, Baur J, Celestin F, Chen X, Michael A, Haq S, Nuedling S, Grohe C et al. 2004 17ß-Estradiol reduces cardiomyocyte apoptosis in vivo and in vitro via activation of phosphoinositide-3 kinase/AKT signaling. Circulation Research 95 692-699.

Pedram A, Razandi M, Wallace DC \& Levin ER 2006 Functional estrogen receptors in the mitochondria of breast cancer cells. Molecular Biology of the Cell 17 2125-2137.

Pettersson K, Delaunay F \& Gustafsson JA 2000 Estrogen receptor beta acts as a dominant regulator of estrogen signaling. Oncogene 19 4970-4978.

Plotkin LI, Aguirre JI, Kousteni S, Manolagas SC \& Bellido T 2005 Bisphosphonates and estrogens inhibit osteocyte apoptosis via distinct molecular mechanisms downstream of extracellular signal-regulated kinase activation. Journal of Biological Chemistry 280 7317-7325.

Razandi M, Pedram A \& Levin ER 2000 Plasma membrane estrogen receptors signal to antiapoptosis in breast cancer. Molecular Endocrinology 14 1434-1447.

Reed JC 1997 Cytochrome $c$ : can't live with it-can't live without it. Cell 91 559-562.

Ropero AB, Soria B \& Nadal A 2002 A nonclassical estrogen membrane receptor triggers rapid differential actions in the endocrine pancreas. Molecular Endocrinology 16 497-505.

Sandri M \& Carraro U 1999 Apoptosis of skeletal muscles during development and disease. International Journal of Biochemistry and Cell Biology 31 1373-1390

Seli E, Guzeloglu-Kayisli O, Kayisli UA, Kizilay G \& Arici A 2007 Estrogen increases apoptosis in the arterial wall in a murine atherosclerosis model. Fertility and Sterility 88 1190-1196.

Simoncini T, Hafezi-Moghadam A, Brazil DP, Ley K, Chin WW \& Liao JK 2000 Interaction of oestrogen receptor with the regulatory subunit of phosphatidylinositol kinase. Nature 407 538-541.
Snedecor GW \& Cochran WG 1967 Statistical Methods., Ames, Iowa: The Iowa State University Press.

Solakidia S, Psarrab MG \& Sekerisa CE 2005 Differential subcellular distribution of estrogen receptor isoforms: localization of ERa in the nucleoli and ERh in the mitochondria of human osteosarcoma SaOS-2 and hepatocarcinoma HepG2 cell lines. Biochimica et Biophysica Acta $\mathbf{1 7 4 5}$ 382-392.

Spyridopoulos I, Sullivan A, Kearney M, Isner JM \& Losordo DW 1997 Estrogen-receptor-mediated inhibition of human endothelial cell apoptosis. Estradiol as a survival factor. Circulation 6 1505-1514.

Sudoh N, Toba K, Akishita M, Ako J, Hashimoto M, Iijima K, Kim S, Liang YQ, Ohike Y, Watanabe Tet al. 1998 Mitochondria as regulators of apoptosis: doubt no more. Biochimica et Biophysica Acta 1366 151-165.

Susin SA, Daugas E, Ravagnan L, Samejima K, Zamzami N, Loeffler M, Costantini P, Ferri KF, Irinopoulou T, Prevost MC et al. 2000 Two distinct pathways leading to nuclear apoptosis. Journal of Experimental Medicine 192 571-580.

Tsai MJ \& O'Malley BW 1994 Molecular mechanisms of action of steroid/thyroid receptor superfamily members. Annual Review of Biochemistry 63 451-486.

Vanhaesebroeck B, Leevers SJ, Ahmadi K, Timms J, Katso R, Driscoll PC, Woscholski R, Parker PJ \& Waterfield MD 2001 Synthesis and function of 3- phosphorylated inositol lipids. Annual Review of Biochemistry 70 535-602.

Walsh K 1997 Coordinate regulation of cell cycle and apoptosis during myogenesis. Progress in Cell Cycle Research 3 53-58.

Watson GH \& Muldoon TG 1985 Specific binding of estrogen and estrogenreceptor complex by microsomes from estrogen-responsive tissues of the rat. Endocrinology 117 1341-1349.

Watson CS, Norfleet AM, Pappas TC \& Gametchu B 1999 Rapid actions of estrogens in GH3/B6 pituitary tumor cells via a plasma membrane version of estrogen receptor-alpha. Steroids 64 5-13.

Wiik A, Glenmark B, Ekman M, Esbjornsson-Liljedahl M, Johansson O, Bodin K, Enmark E \& Jansson E 2003 Oestrogen receptor beta is expressed in adult human skeletal muscle both at the mRNA and protein level. Acta Physiologica Scandinavica 179 381-387.

Xu Q, Simpson SE, Scialla TJ, Bagg A \& Caroll M 2003 Survival of acute myeloid leukaemia cells requires PI3 kinase activation. Blood 102 972-980.

Yang SH, Liu R, Perez EJ, Wen Y, Stevens SM, Valencia T, Brun-Zinkernagel AM, Prokai L, Will Y, Dykens J et al. 2004 Mitochondrial localization of estrogen receptor beta. PNAS 101 4130-4135.

Yano S, Tokumitsu H \& Soderling TR 1998 Calcium promotes cell survival through CaM-K kinase activation of the protein-kinase-B pathway. Nature 396 584-587.

Zheng J \& Ramirez VD 1999 Purification and identification of an estrogen binding protein from rat brain: oligomycin sensitivity-conferring protein (OSCP), a subunit of mitochondrial F0F1-ATP synthase/ATPase. Journal of Steroid Biochemistry and Molecular Biology 68 65-75.

\section{Received in final form 29 October 2007 Accepted 14 November 2007 Made available online as an Accepted Preprint 14 November 2007}

